Original Research Paper

\title{
Diversity of Soil Arthropods in Suranadi Nature Park, Lombok, and its role on science lesson in elementary and secondary school
}

\author{
Mohammad Liwa Ilhamdi ${ }^{1 *}$ \& Mhammad Syazali ${ }^{2}$ \\ ${ }^{1}$ Pendidikan Biologi, Universitas Mataram, Mataram, Indonesia \\ ${ }^{2}$ Pendidikan Guru Sekolah Dasar, Universitas Mataram, Mataram, Indonesia
}

\author{
Article History \\ Received : August 30th, 2021 \\ Revised : September 20th 2021 \\ Accepted : September 27th, 2021 \\ Published : October 02th 2021 \\ *Corresponding Author: \\ Mohammad Liwa Ilhamdi, \\ Universitas Mataram,Mataram, \\ Indonesia; \\ Email: liwa_ilhamdi@unram.ac.id
}

\begin{abstract}
The absence of data related to Arthropoda classes other than the orders Lepidoptera and Odonata in Suranadi Nature Park raises the need for studies on these fauna. This study aims to analyze the soil arthropod community and its role in science lessons in primary and secondary schools. This descriptive research was carried out from May to December 2019. Samples were collected in three paths, namely the forest edge, the middle of the forest and the waterway using the pit fall trap method. The collected samples were identified to species taxon at the Biology Laboratory of the Faculty of Teacher Training and Education, Mataram University. To obtain data on species diversity, an analysis was carried out using the Shannon-Wiener equation. There are 33 species of soil arthropods found. They consist of 3 species from the order Blattodea, 2 species from the order Orthoptera, 4 species from Araneae, 11 species from the order Coleoptera, 10 species from the order Hymenoptera, 1 species each from the orders Homoptera, Tysanura and Diptera. The most abundant species is Platidema sp of the order Coleoptera. Based on the results of the analysis, the diversity index of soil Arthtopoda species in Suranadi Nature Park is 2,628 . The qualitative analysis shows that there are 2 elementary and junior high school science topics that are suitable to be taught using the concept of soil arthropod diversity at Suranadi Nature Park.
\end{abstract}

Keywords: diversity, ground Arthropods, Coleoptera, Suranadi Nature Park.

\section{Pendahuluan}

Berdasarkan distribusi fauna di Indonesia, Lombok merupakan pulau yang "istimewa" karena terletak di antara garis khayal Wallace di sebelah barat dan Weber di sebelah timur. Garis Wallace memisahkan fauna di Lombok dengan fauna Oriental. Garis Weber memisahkan fauna di Lombok dengan fauna Australian. Secara spesifik, Lombok juga termasuk salah satu pulau Lesser Sunda yang membedakannya dengan kawasan Wallace di sebelah utara. Kondisi geografis ini menyebabkan banyak fauna endemik yang ada di Lombok. Dari kelas Aves di antaranya terdapat spesies Celepuk Rinjani (Otus jolandae) dan Koakkaok atau Philemon buceroides (Coates \& Bishop,

This article is licensed under a Creative Commons Attribution 4.0 International License.
2000; Sangster et al., 2013). Dari kelas Amfibi terdapat lima spesies endemik yaitu Oreophryne monticola, Limnonectes kadarsani, Limnonectes dammermani, Hylarana florensis dan Ingerophrynus biporcatus (Iskandar, 1998; Iskandar et al., 1996). Dari kelas mamalia terdapat spesies Paradoxurus hermaphroditus rinjanicus atau Musang Rinjani dan Trachypithecus auratus auratus (Corbet \& Hill, 1992). Dari ordo Coleoptera, beberapa spesies dinamakan dari istilah "Lombok" yang dilatinkan. Spesies-spesies ini adalah Lema (Petauristes) sumbawensis lomboki, Hespera lombokana, Sapitia lombokiana, Scaphisoma lombokense, Scaphobaeocera lombokensis, Kunbir lombokiana dan Merionoeda (Merionoeda) lombokiana (Beitr \& Serie, 2008; 
Löbl, 2015; Tatsuya \& Yaheita, 2015; Yokoi, 2015)

Upaya konservasi yang telah dilakukan dalam rangka melestarikan fauna endemik maupun nonendemik, beberapa kawasan ditetapkan sebagai kawasan konservasi. Salah satu kawasan ini adalah TWA Suranadi. Walaupun dikelilingi oleh daerah urban dan menjadi spot wisata, TWA ini memiliki relung ekologi yang mampu mendukung berbagai kehidupan fauna. Beberapa di antaranya Aves (Zaen \& Rita, 2018), Amfibi (Syazali et al., 2019), mamalia (Nurwahid \& Nizar, 2018), dan berbagai spesies Arthropoda. Kelompok Arthropoda yang telah dilaporkan adalah ordo Lepidoptera (Ilhamdi et al., 2018) dan Odonata (Ilhamdi et al., 2021). Dari ordo Lepidoptera telah tercatat 40 spesies yang diwakili oleh 5 famili. Satu di antaranya merupakan spesies endemik - Troides helena. Spesies yang paling melimpah adalah Jamides celeno. Secara komunitas, indeks keanekaragaman spesiesnya berkisar dari 2.63 - 3.43. Dari ordo Odonata terdapat 18 spesies yang diwakili oleh 5 famili. Satu spesies - Pseudagrion pilidorsum declaratum - merupakan spesies endemik. Spesies yang paling melimpah adalah Othetrum sabina.

Arthropoda selain ordo Lepidoptera dan Odonata belum memiliki catatan diversitas di TWA Suranadi. Ditinjau dari perumusan model manajemen konservasi yang baik, maka data ordo lainnya adalah kebutuhan. Di sisi lain, upaya konservasi tidak akan optimal tanpa keterlibatan masyarakat. Salah satu cara efektif untuk mengenalkan potensi Arthropoda ke masyarakat adalah mengintegrasikannya ke dalam pelajaran sains ke peserta didik karena mereka merupakan generasi penerus yang pada masanya akan bertanggung jawab pada upaya konservasi. Hal ini karena pengenalan potensi lokal dapat menumbuhkan karakter dan literasi konservasi mereka (Prihastari \& Widyaningrum, 2018; Sari et al., 2020; Tresnawati, 2018). Ini akan dapat mendorong mereka melakukan aksi nyata dalam menjaga kelestarian Arthropoda. Selain itu, pemanfaatan fauna di lingkungan sekitar peserta didik berdampak positif terhadap proses dan hasil belajar mereka (Kristyowati \& Purwanto, 2019).

Berdasarkan permasalahan-permasalahan yang telah diungkapkan sebelumnya, kami melakukan penelitian terkait Arthropoda di TWA Suranadi. Tujuan dari penelitian ini adalah menganalisis: (1) keanekaragaman spesies dari Arthropoda tanah, dan (2) perannya pada pelajaran sains di Sekolah Dasar (SD) dan menengah (SMP). Hasil dari penelitian ini dapat dimanfaatkan untuk memperkaya khasanah pengetahuan terkait kelas Arthropoda di TWA Suranadi, referensi penelitian Arthropoda selanjutnya dan data dasar sebagai bahan pertimbangan dalam merancang manajemen konservasi yang lebih baik. Adapun data peran dari produk sains terkait keanekragaman Arthropoda tanah di TWA Suranadi yang sesuai untuk pelajaran pada beberapa topik sains SD dan SMP dapat bermanfaat sebagai bahan pengembangan media pembelajaran kontekstual.

\section{Bahan dan Metode}

\section{Waktu dan tempat}

Penelitian Arthropoda ini dilakukan di TWA Suranadi yang terletak di desa ekowisata Suranadi kecamatan Narmada, Lombok Barat (gambar 1). Pengumpulan sampel Arthropoda tanah dilakukan dengan menggunakan metode pit fall trap. Perangkap dipasang di tiga jalur yaitu jalur pinggir hutan, tengah hutan dan jalur air. Jalur pinggir hutan merupakan kawasan di sepanjang lintasan yang mengelilingi hutan TWA Surandi. Kawasan ini memiliki karakteristik dengan kondisi yang dipengaruhi oleh aktivitas masyarakat sekitar karena berbatasan dengan daerah pemukiman, sawah dan kebun masyarakat sekitar. Jalur tengah hutan memiliki serasah yang melimpah dan tutupan pepohonan yang relatif rapat, sehingga hanya di beberapa titik tertentu sinar matahari sampai ke lantai hutan. Jalur air merupakan area di pinggir kiri dan kanan sungai kecil dengan panjang 400-an meter. Di beberapa bagian pinggir kiri dan kanan ditembok menggunakan beton. 




Gambar 1. Peta Lokasi Penelitian

\section{Alat dan bahan}

Total ada 12 jenis alat dan 5 jenis bahan habis pakai yang digunakan pada penelitian ini. Alat dan bahan tersebut difungsikan selama pengumpulan sampel di lapangan dan koleksi data di laboratorium. Adapun jenis alat dan bahan tersebut beserta pemanfaatannya disajikan pada Tabel 1 berikut ini.

Tabel 1. Jenis-jenis alat dan bahan yang digunakan selama penelitian beserta fungsinya masing-masing.

\begin{tabular}{cll}
\hline No & Jenis Alat dan Bahan & Pemanfaatannya dalam Penelitian \\
\hline Alat-alat: & \\
\hline 1 & Linggis & Penggalian lubang di tanah tempat pemasangan perangkap \\
2 & Gelas plastik & Perangkap jebak \\
3 & Seng tudung pelindung & Pelindung perangkap jebak \\
4 & Botol plastik air mineral & Wadah pembuatan larutan deterjen \\
5 & Kantung plastik bening & Tempat penyimpanan sementara cairan penjebak dan sampel Arthropoda \\
6 & Tas kresek & Tempat pengumpulan kantong plastik berisi cairan dan sampel Arthropoda \\
7 & Cawan petri & Wadah menaruh sampel ketika identifikasi \\
8 & Pinset & Memindahkan sampel Arthropoda tanah saat identifikasi spesies \\
9 & Pipet tetes & Mengatur volume cairan pada cawan petri \\
10 & Loop & Memperbesar ukuran sampel secara visual agar mudah diidentifikasi \\
11 & Mikroskop stereo & Memperbesar ukuran sampel secara visual agar mudah diidentifikasi \\
12 & Kamera Nicon & Mengambil foto kegiatan dan hasil penelitian \\
\hline
\end{tabular}




\begin{tabular}{lll}
\hline \multicolumn{2}{l}{ Bahan - bahan: } & \\
\hline 13 & Formalin 4\% & Mencegah pembusukan pada sampel oleh mikroorganisme dekomposer \\
14 & Air & Melarutkan deterjen untuk bahan cairan penjebak \\
15 & Deterjen & Mengurangi gaya Arcimedes pada permukaan cairan penjebak \\
16 & Pilok & Menandai tempat pemasangan perangkap jebak \\
17 & Alkohol 70\% & Mengawetkan dan Membersihkan sampel saat pengamatan di laboratorium \\
\hline
\end{tabular}

\section{Prosedur penelitian}

Penelitian ini dilakukan melalui tiga tahapan yaitu (1) pengumpulan sampel Arthropoda tanah di kawasan TWA Suranadi, (2) pengumpulan data kekayaan spesies dan jumlah individu masingmasing spesies di Laboratorium Biologi FKIP Universitas Mataram, dan (3) mereview dokumen untuk menentukan topik sains SD dan SMP yang potensial untuk disubstitusikan konsep keanekaragaman Arthropoda tanah. Tahapan pengumpulan sampel dilakukan di TWA Suranadi dengan memasang 20 perangkap di tiga tipe habitat. Sebanyak 10 perangkap dipasang di jalur pinggir hutan, dan masing-masing 5 perangkap di jalur tengah hutan dan jalur air. Replikasi sebanyak lima kali $(5 x)$ di mana interval waktu dari tiap pengulangan adalah satu minggu. Tahap 2 dilakukan di Laboratorium Biologi Dasar FKIP Universitas Mataram. Nama spesies mengacu pada (Borror et al., 1992; Dindal, 1990; Harding \& Moore, 1926). Dokumen yang direview pada tahap tiga adalah Permendikbud No. 37 Tahun 2018.

\section{Analisis data}

Analisis data mencakup analilsis secara kuantitatif dan kualitatif. Analisis data secara kuantitatif dilakukan untuk mengukur kelimpahan relatif dan indeks keanekragaman spesies. Indeks keanekaragaman spesies diukur menggunakan persamaan indeks Shannon-Wiener. Adapun analisis secara kualitatif bertujuan untuk mengetahui peranan produk sains terkait keanekaragaman Arthropoda tanah di TWA Suranadi pada pelajaran sains di SD dan SMP. Analisis ini mencakup review dokumen terkait standar isi sains SD berdasarkan Permendikbud No. 37 Tahun 2018. Hasil review yaitu topik-topik potensial, dikomparasikan dengan produk sains terkait keanekaragaman Arthropoda tanah di TWA Suranadi menggunakan metode komparatif (Sulaeman et al., 2020). Seorang guru sains SD \& SMP, dan dua orang dosen sains dilibatkan untuk memberikan penilaian terhadap tingkat kesesuaian produk sains terkait keanekaragaman Arthropoda tanah dan topik-topik potensial. Tingkat kesesuaian tersebut dibedakan menjadi 5 kategori yaitu sangat rendah, rendah, cukup, tinggi dan sangat tinggi.

\section{Hasil dan Pembahasan}

\section{Komposisi spesies}

Spesies Arthropoda tanah yang ditemukan dari hasil penelitian ini adalah 33 spesies dari takson Blatodea (3 spesies), Orthoptera (2 spesies), Araneae (4 spesies), Coleoptera (11 spesies), Hymenoptera (10 spesies), Homoptera, Thysanura dan Diptera masing-masing spesies (Tabel 1). Lima spesies di antaranya terdistribusi di semua tipe habitat yaitu jalur air, tengah hutan dan tepi hutan. Spesies-spesies ini adalah Linipidae sp., Platydema sp., Oxylobus meridionalis, Dolichoderus bituberculatus dan Thysanura sp. Empat spesies terdistribusi di dua tipe habitat yaitu jalur air dan tengah hutan. Spesies-spesies ini adalah Blatta germanata, Gryllus asimilis, Phaneus sp dan Paranemus subcupreus. Adapun spesies-spesies lainnya hanya terdistribusi di tipe habitat jalur air. 
Tabel 1. Komposisi dan distribusi spesies Arthropoda tanah di TWA Suranadi

\begin{tabular}{|c|c|c|c|c|}
\hline \multirow{2}{*}{ Takson } & \multirow{2}{*}{ Spesies } & \multicolumn{3}{|c|}{ Tipe Habitat } \\
\hline & & Jalur Air & Tengah Hutan & Pinggir Hutan \\
\hline \multirow[t]{3}{*}{ Blatodea } & Blatta germanata & + & + & - \\
\hline & Gryllus asimilis & + & + & - \\
\hline & Gryllotalpa sp. & + & - & - \\
\hline \multirow[t]{2}{*}{ Orthoptera } & Melanoplus femurrubrum & + & - & - \\
\hline & Julus nemoreasis & + & - & - \\
\hline \multirow[t]{4}{*}{ Araneae } & Linipidae sp & + & + & + \\
\hline & Epiera angulata & + & - & - \\
\hline & Argiope aurelia & + & - & - \\
\hline & Latrodectus mactans & + & - & - \\
\hline \multirow[t]{11}{*}{ Coleoptera } & Platydema sp & + & + & + \\
\hline & Tachis blandus & + & - & - \\
\hline & Myrmex sp & + & - & - \\
\hline & Oxylobus meridionalis & + & + & + \\
\hline & Agonum sp & + & - & - \\
\hline & Phaneus sp & + & + & - \\
\hline & Paranemus subcupreus & + & + & - \\
\hline & Erycorinus sp & + & - & - \\
\hline & Euspilotus sp & + & - & - \\
\hline & Dinopelma leptaleum & + & - & - \\
\hline & Oxyporus sp & + & - & - \\
\hline \multirow[t]{10}{*}{ Hymenoptera } & Dolichoderus bituberculatus & + & + & + \\
\hline & Acoenitus sp & + & - & - \\
\hline & Odontomachus ponera & + & - & - \\
\hline & Camponutus taulori & + & - & - \\
\hline & Bothriomyrmex myops & + & - & - \\
\hline & Camponutus herculeanus & + & - & - \\
\hline & Vespa affinis & + & - & - \\
\hline & Lobupelta ocelifera & + & - & - \\
\hline & leptogenys elongata & + & - & - \\
\hline & Polyrhachis hauxiselli & + & - & - \\
\hline Homoptera & Homoptera sp & + & - & - \\
\hline Thysanura & Tysanura sp & + & + & + \\
\hline Diptera & Musca domestica & + & - & - \\
\hline
\end{tabular}

Takson yang paling melimpah adalah ordo Coleoptera. Kelimpahan relatifnya sebesar $44 \%$ dengan jumlah spesimen yang tertangkap pada perangkap sejumlah 70 spesimen. Diurutan kedua dengan kelimpahan paling tinggi adalah takson
Blatodea, dan disusul oleh ordo Hymenoptera. Kelimpahan relatif kedua takson secara berurutan adalah $26 \%$ dan $19 \%$. Jumlah spesimen yang berhasil dikumpulkan sebanyak 42 spesimen dari Blatodea dan 30 spesimen dari Hymenoptera. 
Adapun takson lainnya memiliki kelimpahan relatif yang berkisar dari $0.6 \%$ sampai dengan $5 \%$ (Gambar 2). Ordo Blattodea hanya terdiri dari 3 spesies. Ini jauh lebih sedikit dari kekayaan spesies dari ordo Coleptera dan Hymenoptera yang masing-masing terdiri dari 11 dan 10 spesies.

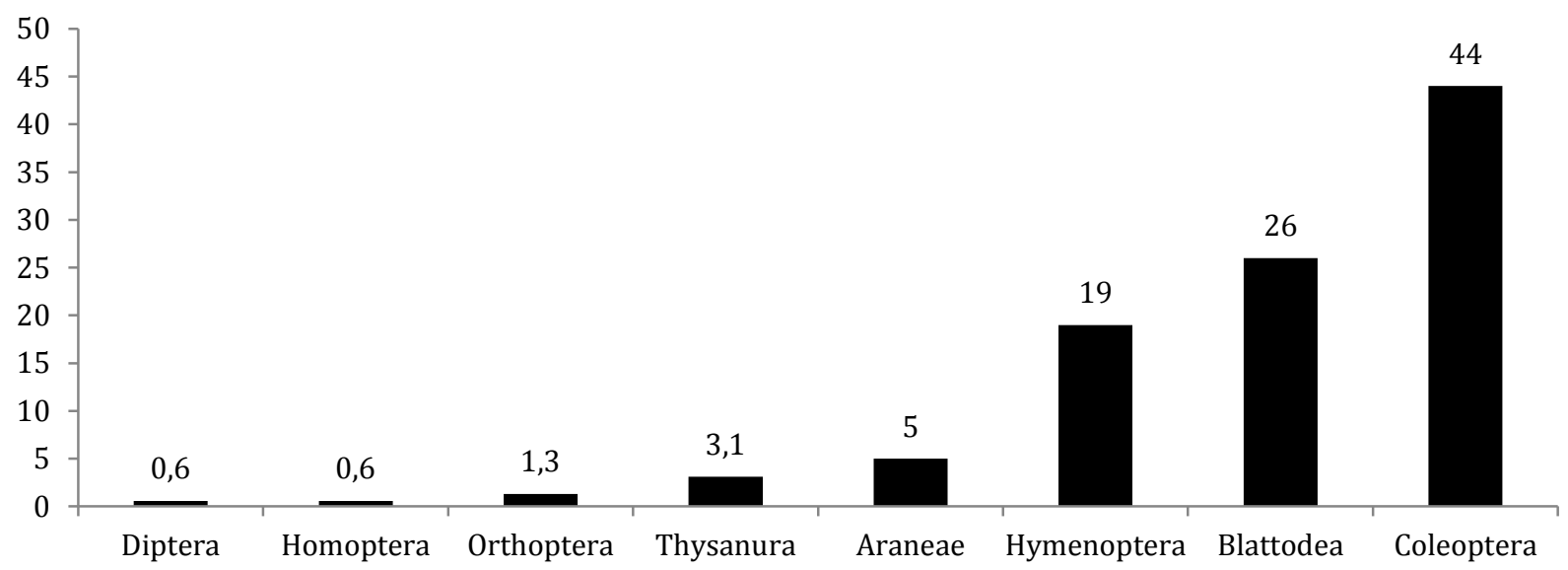

Gambar 2. Kelimpahan relatif masing-masing takson dari Arthropoda tanah di TWA Suranadi

Kelimpahan ordo Coleoptera yang paling tinggi disebabkan oleh kekayaan spesiesnya yang paling besar. Di antara serangga dan bahkan seluruh spesies dari kingdom animalia, takson ini memiliki anggota dengan jumlah spesies paling besar. Jumlah spesies yang telah berhasil teridentifikasi berjumlah 400,000 spesies di seluruh dunia (Gilliott, 1995). Jumlah ini diperkirakan masih lebih sedikit dari jumlah spesies yang sebenarnya. Di Indonesia, diperkirakan terdapat 10\% dari jumlah spesies yang ada di bumi (Shahabuddin et al., 2005). Penelitian-penelitian yang telah dilakukan sebelumnya memperkuat fakta ini. Beberapa di antaranya adalah hasil penelitian di beberapa tipe habitat di Pulau Lombok (Rohyani, 2020). Jumlah familinya jauh lebih besar dibandingkan dengan famili-famili lain pada kelas Arthropoda. Ini mengindikasikan komposisi spesies yang juga paling tinggi. Demikian pula dengan kelimpahannya. Pada habitat perkebunan balangeran di Sumatera Selatan, kelimpahan ordo Coleoptera juga lebih tinggi dibandingkan dengan ordo dari kelas insekta tanah lainnya seperti Lepidopetra, Hymenoptera, Orthoptera, Hemiptera, Diptera dan Homoptera (Utami et al., 2020).
Kekayaan spesies ordo Blattodea bahkan lebih kecil dibandingkan dengan ordo Araneae. Kelimpahan yang tinggi dari ordo ini menunjukkan bahwa populasi dari spesies yang menyusunnya berukuran cukup besar. 


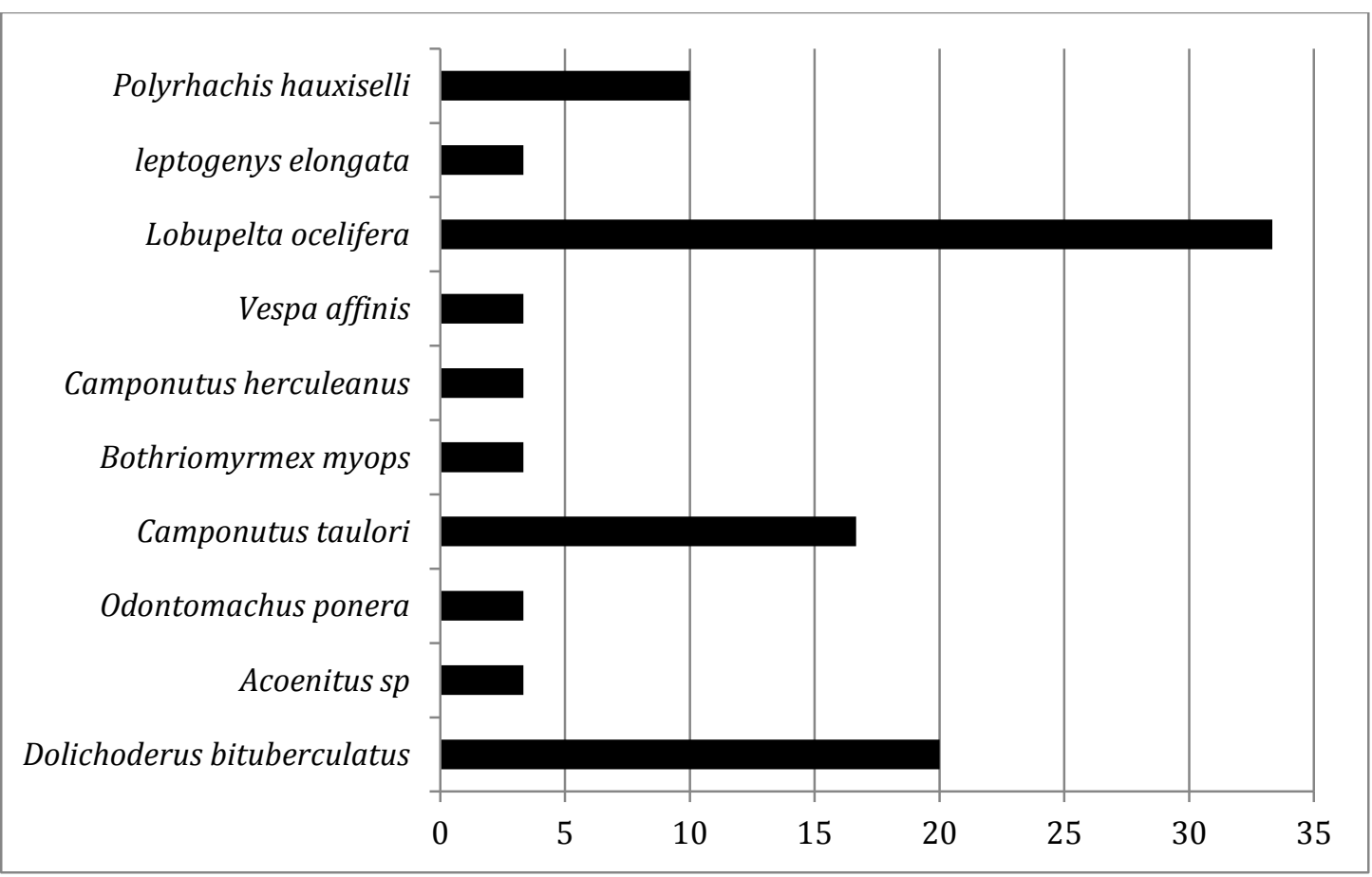

Gambar 3. Kelimpahan spesies dari ordo Hymenoptera

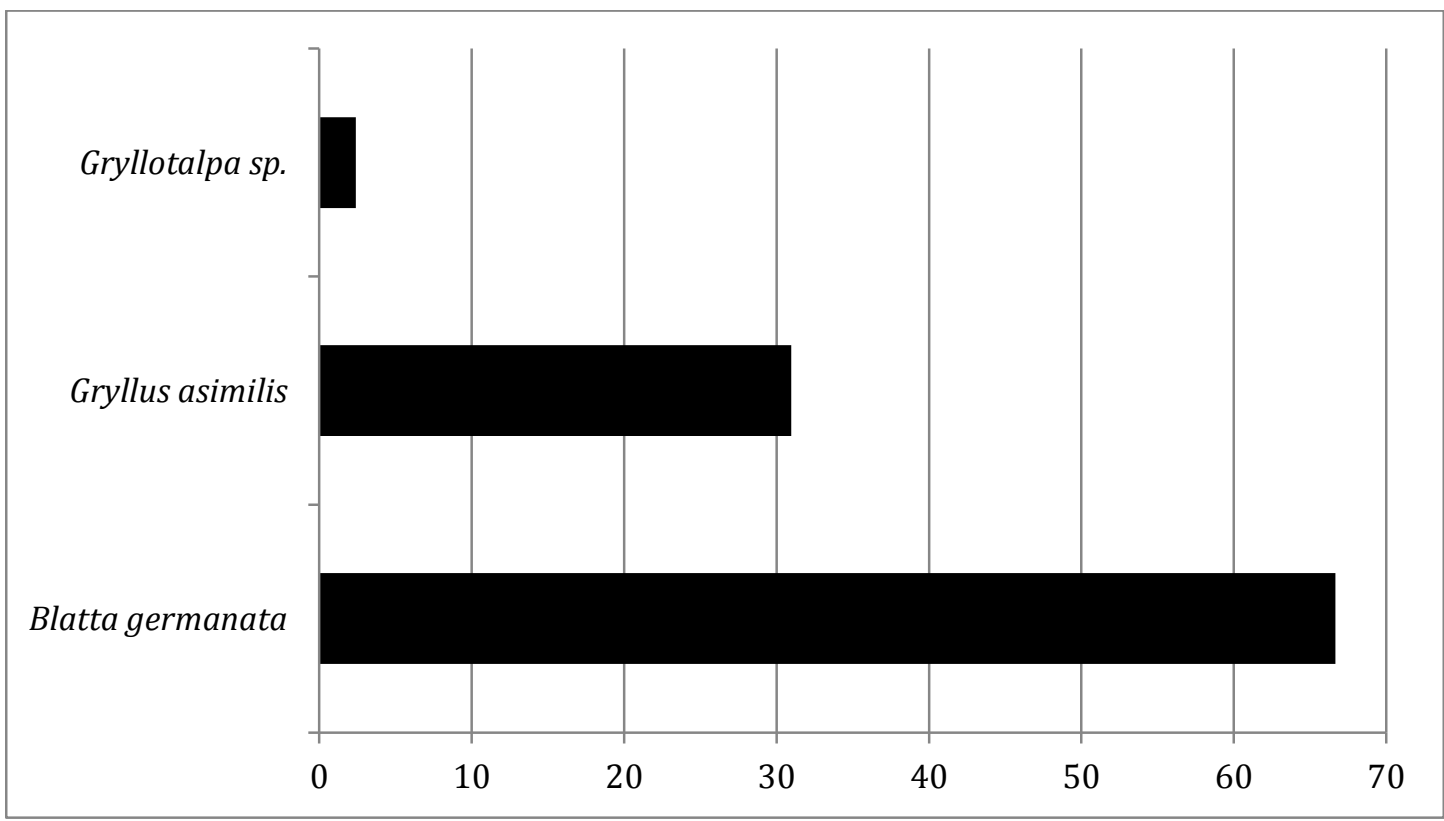

Gambar 4. Kelimpahan spesies dari ordo Blattodea 




Gambar 5. Kelimpahan spesies dari ordo Coleoptera

\section{Keanekaragaman tingkat jenis}

Indeks keanekaragaman spesies dari Arthropoda tanah di TWA Suranadi adalah 2.628. Indeks ini menunjukkan bahwa daya dukung lingkungan - kondisi dan sumberdaya - di TWA Suranadi lebih baik untuk mendukung kehidupan Arthropoda tanah dibandingkan dengan dibeberapa lokasi tertentu, seperti Lumajang, Universitas Bengkulu, Musi Banyuasin, dan Sigi. Indeks keanekaragaman spesies di kawasan Restorasi Ranu Panu, Lumajang sebesar 1.899 (Ardillah et al., 2014). Adapun indeks keanekaragaman Arthropoda tanah di kawasan konservasi Universitas Bengkulu, kawasan sumur minyak Musi Banyuasin dan ladang cabai di Sigi secara berurutan adalah 1.170, $0.57-0.95$ dan 1.52 - 1.83 (Agustinawati et al., 2016; Muli et al., 2015; Suterisni et al., 2018). Namun indeks keanekaragaman spesies pada ekosistem sawah di Lombok Tengah lebih tinggi (Stella et al., 2020). Indeks keanekaragamannya tergolong tinggi dengan nilai sebesar 3.18. Ini mengindikasikan bahwa habitat-habitat tersebut memiliki daya dukung lingkungan yang relatif lebih baik.
Jika ditinjau dari tipe habitat, indeks keanekaragaman paling tinggi ditemukan di jalur air, kemudian diikuti oleh tengah hutan dan pinggir hutan. Secara berurutan, indeks keanekaragaman spesiesnya adalah 2.611, 1.756 dan 1.471 (Tabel 2). Perbedaan indeks keanekaragaman spesies ini disebabkan oleh adanya perbedaan kekayaan spesies pada masing-masing tipe habitat. Secara matematis, kekayaan spesies berbading lurus dengan indeks kenaekaragaman spesies (Shannon, 1948). Artinya bahwa semakin besar kekayaan spesies, maka semakin besar pula indeks keanekaragaman spesies komunitas. Pada Arthropoda tanah yang ditemukan di TWA Suranadi, kekayaan spesies di tipe habitat jalur air merupakan yang paling tinggi dibandingkan dengan kekayaan spesies di tipe habitat lainnya. Ini yang menyebabkan indeks keanekaragaman spesiesnya juga paling tinggi. Dari aspek luas area, sebenarnya jalur pinggi hutan dan tengah hutan jauh leih tinggi dibandingkan dengan jalur air. Namun mikrohabitat pada kedua jalur tersebut cenderung homogen. Ini berbeda dengan jalur air yang memiliki mikrohabitat yang lebih beragam. 
Tabel 2. Indeks keanekaragaman Arthropoda tanah pada masing-masing tipe habitat

\begin{tabular}{clccc}
\hline No & Tipe Habitat & Kekayaan Spesies & Total spesimen & Indeks Keanekaragaman (H') \\
\hline 1 & Jalur air & 33 & 105 & 2.611 \\
2 & Jalur tengah hutan & 9 & 44 & 1.756 \\
3 & Jalur pinggir hutan & 5 & 10 & 1.471 \\
\hline
\end{tabular}

\section{Peranan dalam Pelajaran Sains SD dan SMP}

Produk sains yang terkait keanekaragaman Arthropoda tanah hasil penelitian di TWA Suranadi berperan pada pelajaran sains di SD dan SMP. Ini dapat diamati dari adanya topik potensial yang memiliki tingkat kesesuaian dengan kategori tinggi (Tabel 3). Topik-topik ini di antaranya "Keseimbangan dan pelestarian hewan di lingkungan sekitar; dan Klasifikasi makhluk hidup". Adapun topik-topik potensial lainnya memiliki tingkat kesesuaian dengan kategori sangat rendah sampai dengan cukup. Terdapat empat topik yang memiliki tingkat kesesuaian sangat rendah. Topik-topik ini adalah Siklus hidup hewan dan mengaitkan dengan upaya pelestariannya, Morfologi dan fungsi tubuh hewan, Adaptasi pada hewan dan Pencemaran lingkungan. Dua topik memiliki tingkat kesesuaian yang rendah. Topik-topik ini adalah Sistem organisasi kehidupan dan Perubahan iklim dan dampaknya terhadap ekosistem. Dua topik memiliki tingkat kesesuaian dengan kategori cukup. Dua topik ini adalah Ekosistem dan jaring-jaring makanan di lingkungan sekitar dan Interaksi makhluk hidup.

Tabel 3. Tingkat kesesuaian konsep keanekaragaman Arthropoda tanah pada pelajaran sains

\begin{tabular}{clcc}
\hline No & Topik Potensial & $\begin{array}{c}\text { Tingkat } \\
\text { Kesesuaian }\end{array}$ & Kategori \\
\hline \multicolumn{2}{c}{ Sekolah Dasar (SD) } & 3 & Cukup \\
1 & Ekosistem dan jaring-jaring makanan di lingkungan sekitar & 1 & Sangat rendah \\
2 & Siklus hidup hewan dan mengaitkan dengan upaya pelestariannya & 4 & Tinggi \\
3 & Keseimbangan dan pelestarian hewan di lingkungan sekitar & 1 & Sangat rendah \\
4 & Morfologi dan fungsi tubuh hewan & 1 & Sangat rendah \\
5 & Adaptasi pada hewan & & \\
\hline Sekolah Menengah Pertama (SMP) & 4 & Tinggi \\
6 & Klasifikasi makhluk hidup & 2 & Rendah \\
7 & Sistem organisasi kehidupan & 3 & Cukup \\
8 & Interaksi makhluk hidup & 1 & Sangat rendah \\
9 & Pencemaran lingkungan & 2 & Rendah \\
10 & Perubahan iklim dan dampaknya terhadap ekosistem & & \\
\hline
\end{tabular}

Topik-topik sains dengan tingkat kesesuaian yang kategorinya berada di bawah kategori tinggi bukan berarti tidak bisa disubstitusikan dengan konsep keaneakaragaman Arthropoda tanah di TWA Suranadi. Misalnya pada topik Siklus hidup hewan dan mengaitkan dengan upaya pelestariannya yang dipelajari di SD. Fauna Arthropoda menjadi contoh umum untuk menggambarkan siklus hidup hewan. Ini dikarenakan memiliki struktur morfologi dan anatomi yang ekstrim pada tiap fase pertumbuhan dan perkembangannya - metamorfosis. Metamorfosis pada Arthropoda juga lengkap yaitu ada spesies yang melakukan metamorfosis sempurna (holometabola), dan spesies lainnya mengalami metamorfosis tidak sempurna (hemimetabola). Di sisi lain, upaya konservasi merupakan konsen utama dari pendataan keanekaragaman hayati termasuk Arthropoda.

Topik Keseimbangan dan pelestarian hewan di lingkungan sekitar merupakan topik yang memiliki tingkat kesesuaian dengan kategori tinggi. Demikian pula dengan topik Klasifikasi makhluk hidup. Konsep keanekaragaman Arthropoda secara langsung dapat disubstitusikan ke dalam kedua topik tersebut. Ini dikarenakan 
keberadaan dari Arthropoda di TWA Suranadi berperan dalam menjaga keseimbangan ekosistem, dan menjadi sumberdaya hayati yang dikonservasi mengacu pada Surat Keputusan Menteri Kehutanan No. 646/Kpts/Um/10/76 Tahun 1976. Selain itu, hasil penelitian keanekaragaman Arthropoda tanah yang menunjukkan adanya takson kelas, ordo dan spesies merupakan bentukbentuk klasifikasi secara ilmiah. Ini tentunya dapat dijadikan sebagai contoh dalam pembelajaran sains pada topik Klasifikasi makhluk hidup. Upaya ini dapat memperkaya konten sains yang selama ini cenderung terbatas pada hewan vertebrata dan tumbuhan tingkat tinggi pada kedua topik tersebut.

Rekontekstualisasi fenomena alam di lingkungan sekitar ke dalam pelajaran sains di sekolah menghasilkan sumber belajar yang bersifat kontekstual. Ini memberikan manfaat positif, baik pada proses maupun hasil pembelajaran. Dari aspek proses pembelajaran sains, implementasi sumber belajar kontekstual mampu meningkatkan minat belajar (Irwandi \& Fajeriadi, 2019). Dari aspek hasil belajar sains, peningkatan tidak hanya terjadi pada kompetensi produk sains - penguasaan konsep, namun juga pada sikap dan keterampilan proses sains (Istijabatun et al., 2016). Pada tataran implementasi, sumber belajar kontekstual ini juga dapat disesuaikan dengan budaya lokal setempat. Di samping pemenuhan tuntutan kurikulum, juga berdampak pada peningkatan kualitas pembelajaran (Kristyowati \& Purwanto, 2019). Dampak menguntungkan ini juga dapat diperoleh pada kolaborasinya dengan implementasi berbagai model pembelajaran seperti problem based learning, project based learning, dan contextual teaching and learning.

\section{Kesimpulan}

Di TWA Suranadi telah berhasil ditemukan 33 spesies Arthropoda tanah dari ordo Blattodea, Orthoptera, Araneae, Coleoptera, Hymenoptera, Homoptera, Tysanura dan Diptera. Spesies yang paling melimpah adalah Platidema $s p$ dari ordo Coleoptera. Indeks keanekaragaman spesies termasuk sedang dengan nilai sebesar 2.628. Hasil analisis kualitatif menunjukkan bahwa produk sains terkait keanekaragaman Arthropoda tanah di TWA Suranadi ini berperan penting dalam pelajran sains di SD. Hal ini teramti dari adanya beberapa topik yang sesuai untuk diajarkan. Topik- topik tersebut di antaranya "Keseimbangan dan pelestarian hewan di lingkungan sekitar", dan "Klasifikasi makhluk hidup".

\section{Referensi}

Agustinawati, Toana, M. H., \& Wahid, A. (2016). Keanekaragaman arthropoda permukaan tanah pada tanaman cabai (Capsicum annum L.) dengan sistem pertanaman yang berbeda di Kabupaten Sigi. Jurnal Agrotekbis, 4(1), 8-15.

Ardillah, J. S., Leksono, A. S., \& Hakim, L. (2014). Diversitas Arthropoda tanah di area Restorasi Ranu Pani kabupaten Lumajang. Jurnal Biotropika, 2(4), 208-213.

Beitr, S., \& Serie, N. (2008). New and poorly known Chrysomelidae (Coleoptera) from the islands of Bali and Lombok (Indonesia). Stuttgarter Beiträge Zur Naturkunde A, 1, 431-434.

Borror, D. J., Triplehon, C. A., \& Johnson, N. F. (1992). Pengenalan Pelajaran Serangga. In Edisi Keenam. Yogayakarta: Gadjah Mada University Press.

Coates, B. J., \& Bishop, K. D. (2000). Birds of Wallacea: Celebes, Moluccas and Nusa Tenggara. Bogor: BirdLife InternationalIndonesia Programmed \& Dove Publications Pty Ltd.

Corbet, G. B., \& Hill, J. E. (1992). The Mammals of Indomalayan Region: a systematic review. Oxford: Nat. Hist. Mus. Publ. \& Oxford Univ. Press.

Dindal, D. L. (1990). Soil Biology Guide. New York: Wiley.

Gilliott, C. (1995). Entomology (edisi ke-2). New York: Springer-Verlag.

Harding, W. A., \& Moore, J. P. (1926). The Fauna of British India, including Ceylon and Burma (Vol. 3). Today and Tomorrow Publisher. 
Ilhamdi, M. L., Idrus, A. A. L., Santoso, D., Hadiprayitno, G., \& Syazali, M. (2021). Species richness and conservation priority of dragonflies in the Suranadi Ecotourism Area , Lombok , Indonesia. Biodiversitas, 22(4), $1846-1852$

https://doi.org/10.13057/biodiv/d220430

Ilhamdi, M. L., Idrus, A. Al, \& Santoso, D. (2018). Diversity of species and conservation priority of butterfly at Suranadi Natural Park of West Lombok, Indonesia. Biosantifika: Journal of Biology \& Biology Education, $10(1)$, $48-55$. https://doi.org/10.15294/biosaintifika.v10i1 .10695

Irwandi, \& Fajeriadi, H. (2019). Pemanfaatan lingkungan sebagai sumber belajar untuk meningkatkan minat dan hasil belajar siswa SMA di kawasan pesisir, Kalimantan Selatan. BIO-INOVED: Jurnal BiologiInovasi Pendidikan, 1(2), 66-73.

Iskandar, D. T. (1998). The Amphibians of Java and Bali. Jakarta: Research and Development Centre for Biology-LIPI.

Iskandar, D. T., Boeadi, \& Sancoyo, M. (1996). Limnonectes kadarsani (Amphibia: Anura: Ranidae), a new frog from the Nusa Tenggara Islands. Raffles Bulletin of Zoology, 44(1), 21-28.

Istijabatun, S., Supartono, \& Masturi. (2016). Pembelajaran kontekstual untuk meningkatkan soft skill konservasi dan keterampilan proses sains. Journal of Innovative Science Education, 5(2), 111120.

Kristyowati, R., \& Purwanto, A. (2019). Pembelajaran literasi sains melalui pemanfaatan lingkungan. Scholaria: Jurnal Pendidikan Dan Kebudayaan, 9(2), 183191.

Löbl, I. (2015). On the Scaphidiinae (Coleoptera: Staphylinidae) of the Lesser Sunda Islands. Revue Suisse de Zoologie, 122(1), 75-120. https://doi.org/10.5281/zenodo.14582
Muli, R., Irsan, C., \& Suheryanto. (2015). Komunitas arthropoda tanah di kawasan sumur minyak bumi di desa Mangunjaya, kecamatan Babat Toman, kabupaten Musi Banyuasin, provinsi Sumatera Selatan. Jurnal Ilmu Lingkungan, 13(1), 1-11.

Nurwahid, W., \& Nizar, W. Y. (2018). Inventarisasi kepadatan populasi monyet ekor panjang (Macaca fascicularis) di Taman Wisata Alam Suranadi kecamatan Narmada kabupaten Lombok Barat. Jurnal Silva Samalas, 1(1), 45-53.

Prihastari, E. B., \& Widyaningrum, R. (2018). Implementasi media mas novel berbasis kearifan lokal untuk penanaman karakter peduli lingkungan pada siswa SD. Seminar Nasional Pendidikan: Mengembangkan Kompetensi Pendidik Dalam Menghadapi Era Disrups, 1-14.

Rohyani, I. S. (2020). Community structure analysis of soil insects and their potential role as bioindicators in various ecosystem types in Lombok, West Nusa Tenggara, Indonesia. Biodiversitas, 21(9), 4221-4227. https://doi.org/10.13057/biodiv/d210937

Sangster, G., King, B. F., Verbelen, P., \& Trainor, C. R. (2013). A new owl species of the genus Otus (Aves: Strigidae) from Lombok, Indonesia. $\quad P L O S \quad O N E, \quad 8(2)$. https://doi.org/10.1371/journal.pone.00537 12

Sari, N. P., Walid, A., Studi, P., Pengetahuan, I., Sains, J., Tarbiyah, F., Agama, I., \& Negeri, I. (2020). Pengembangan modul pembelajaran IPA berbasis etnosains materi interaksi makhluk hidup dengan lingkungannya untuk menanamkan jiwa konservasi siswa kelas VII SMP. BIOEDU : Jurnal Pendidikan Biologi, 5(2), 6273. https://doi.org/10.32938/jbe.v5i2.554

Shahabuddin, S., Hidayat, P., Noerdjito, W. A., \& Manuwoto, S. (2005). Research on insect biodiversity in Indonesia: Dung beetles (Coleoptera: Scarabaeidae) and its role in ecosystem. Biodiversitas Journal of Biological Diversity, 6(2), 141-146. 
Shannon, C. . (1948). A Mathematical theory of communication. The Bell System Technical Journal, 27, 379-423.

Stella, R., Thei, P., Abadi, A. L., Mudjiono, G., \& Suprayogo, D. (2020). The dynamics of Arthropod diversity and abundance in rice field ecosystem in Central Lombok, Indonesia. Biodiversitas, 21(12), 5850 5857.

https://doi.org/10.13057/biodiv/d211249

Sulaeman, N. F., Nuryadin, A., Widyastuti, R., \& Subagiyo, L. (2020). Air quality index and the urgency of environmental education in Kalimantan. Jurnal Pendidikan IPA Indonesia, $\quad 9(3), \quad 371-383$. https://doi.org/10.15294/jpii.v9i3.24049

Suterisni, M., Karyadi, B., \& Winarni, E. W. (2018). Studi keanekaragaman arthropoda tanah di area konservasi Kura-kura Manouria emys Universitas Bengkulu dan pengembangan pembelajaran siswa SMA. PENDIPA: Journal of Science Education, 2(1), 106-112.

Syazali, M., Idrus, A. Al, \& Hadiprayitno, G. (2019). Habitat characteristic and conservation of amphibians in Lombok Island. Biota: Jurnal Biologi Dan Pendidikan Biologi, 12(2), 98-107. https://doi.org/10.20414/jb.v12i2.210
Tatsuya, N., \& Yaheita, Y. (2015). Additional notes on the Stenopterine Fauna (Coleoptera, Cerambycidae) of the Island of Lombok, Indonesia. Elytra, 5(1), 207-216.

Tresnawati, N. (2018). Pembelajaran sains berbasis kearifan lokal dalam upaya peningkatan konservasi lingkungan pada mahasiswa PGSD di batik tulis ciwaringin Cirebon. $A l$ Ibtida: Jurnal Pendidikan Guru MI, 5(1), 69-82.

https://doi.org/10.24235/al.ibtida.snj.v5i1.2 603

Utami, S., Muslimin, I., Kurniawan, A., Azwar, F., \& Purwanto. (2020). Diversity and abundance of arthropods inhabiting peat soil in monoculture and polyculture of balangeran (Shorea balangeran) plantation in South Sumatra, Indonesia. IOP Conf. Series: Earth and Environmental Science, 533, 1-10. https://doi.org/10.1088/1755$1315 / 533 / 1 / 012043$

Yokoi, Y. (2015). Notes on the Callidiopini (Coleoptera, Cerambycidae) across the Lombok Strait. Elytra, 5(1), 185-205.

Zaen, M., \& Rita, R. R. N. D. (2018). Analisis potensi keanekaragaman jenis burung di Taman Wisata Alam Suranadi. Jurnal Silva Samalas, 1(1), 70-75. 